\title{
Causes and management of aortic valve regurgitation after aortic valve reimplantation
}

\author{
Christian Giebels, MD, Diana Aicher, MD, Takashi Kunihara, MD, PhD, Svetlana Rodionycheva, MD, \\ Wolfram Schmied, Dipl Psych, and Hans-Joachim Schäfers, MD
}

\begin{abstract}
Objective: Recurrent aortic regurgitation can occur after valve-preserving aortic replacement. Little is known about the exact mechanisms of valve failure and the best reoperative strategies. We analyzed our experience with reoperation after aortic valve reimplantation.
\end{abstract}

\begin{abstract}
Methods: From November 1995 to August 2011, 13 patients (10 men; age, 18-58 years) underwent reoperation for valve failure after aortic valve reimplantation. The reason for reoperation was aortic regurgitation in 11 and endocarditis in 2 after 6 weeks to 13 years. The morphologic causes of regurgitation were cusp prolapse in 6 , cusp retraction in 4 , cusp perforation in 6 , inadequate commissural height in 5 , commissural dehiscence in 2 , and inadequate valve configuration in 1 , alone or combined. The patients were treated by valve replacement $(n=4)$ or cusp repair $(n=2)$. In 3 patients, composite replacement of the valve and root was necessary, in 1 with a pulmonary autograft. In 4 patients the aortic valve was spared. All patients were followed up regularly.

Results: No patient died early; 1 patient died 4 years after reoperation. One patient required reoperation 2 years after the cusp repair procedure. All patients with repeat valve-preserving root replacement had stable valve function postoperatively. The 5-year survival rate after reoperation was $86 \% \pm 13 \%$. The 5 -year rate of freedom from valve-related complications was $78 \% \pm 14 \%$.

Conclusions: Recurrent aortic regurgitation early after aortic valve reimplantation frequently involves cusp prolapse and a low commissural height; later, cusp retraction becomes more important. Reoperation within the first 6 postoperative months allows for preservation of the native aortic valve; however, beyond this period, valve replacement within the graft will mostly be required. (J Thorac Cardiovasc Surg 2013;145:774-80)
\end{abstract}

In the past 20 years, valve-preserving aortic replacement has become an increasingly accepted alternative to composite replacement of the aortic valve and aorta. Valve reimplantation $^{1}$ has generally been preferred over root remodeling, ${ }^{2}$ and excellent results have been reported from specialized centers. ${ }^{3-6}$

Nevertheless, valve failure with the need for reoperation has occurred after aortic valve reimplantation. ${ }^{3,6-9}$ These reports have described the need for reoperation but not the operative details or the results of these interventions. Most importantly, the anatomic causes for valve failure have not yet been specified. ${ }^{3,6-9}$ Only 1 study has reported the echocardiographic prediction of valve failure by classifying the postoperative aortic valve configuration. ${ }^{10}$ The exact anatomic correlates, including the intraoperative findings at reoperation, were not given. ${ }^{10}$ An exact anatomic and functional analysis of valve failure, however, is

From the Department of Thoracic and Cardiovascular Surgery, University Hospital of Saarland, Homburg/Saar, Germany.

Disclosures: Authors have nothing to disclose with regard to commercial support.

Received for publication Nov 22, 2011; revisions received Jan 10, 2012; accepted for publication March 12, 2012; available ahead of print April 12, 2012.

Address for reprints: Hans-Joachim Schäfers, MD, Department of Thoracic and Cardiovascular Surgery, University Hospital of Saarland, Homburg/Saar, Germany

(E-mail: h-j.schaefers@uks.eu).

$0022-5223 / \$ 36.00$

Copyright (c) 2013 by The American Association for Thoracic Surgery

doi:10.1016/j.jtcvs.2012.03.016 a prerequisite for additional improvement of the results of valve-preserving surgery.

To our knowledge, reoperation has, in all published instances, consisted of aortic valve replacement. Theoretically, it should be possible to save the aortic valve if a correctable anatomic lesion is found. From our previous investigations on the normal configuration of the aortic valve, we have extended the assessment of the regurgitant aortic valve to the failure of valve-preserving aortic replacement. ${ }^{1,12}$ In addition, we have attempted to preserve regurgitant aortic valves at reoperation, applying our established principles of primary aortic valve repair. ${ }^{13,14}$ Over the years, we have had to perform a number of reoperations for valve failure in patients after aortic valve reimplantation.

The purpose of the present investigation was to analyze the operative findings at reoperation and determine the anatomic causes of valve failure. To investigate a patient cohort with relatively homogenous characteristics, we decided to focus on reoperations after valve reimplantation. Because we have been able to save some of the failing valves, we also sought to define the scenarios in which this would be an option.

\section{METHODS}

From November 1995 to August 2011, 13 patients underwent reoperation for severe aortic regurgitation after aortic valve reimplantation at our center. The initial procedure had been performed by us in $5(17 \%$; patients 
TABLE 1. Clinical patient data

\begin{tabular}{|c|c|c|c|c|c|c|c|c|c|c|c|c|}
\hline \multirow[b]{2}{*}{$\begin{array}{l}\text { Pt. } \\
\text { no. }\end{array}$} & \multirow[b]{2}{*}{ Gender } & \multicolumn{4}{|c|}{ Initial operation } & \multirow{2}{*}{$\begin{array}{c}\text { Initial-repeat } \\
\text { surgery } \\
\text { interval }(\mathbf{m}) \\
\end{array}$} & \multicolumn{5}{|c|}{ Reoperation } & \multirow[b]{2}{*}{$\begin{array}{c}\text { Follow-up } \\
(\mathbf{m})\end{array}$} \\
\hline & & $\begin{array}{c}\text { Age } \\
(\mathbf{y})\end{array}$ & Diagnosis & $\begin{array}{l}\text { Aortic valve } \\
\text { morphology }\end{array}$ & $\begin{array}{c}\text { Graft size } \\
(\mathbf{m m})\end{array}$ & & Diagnosis & Age (y) & $\begin{array}{c}\text { Aortic valve } \\
\text { pathology }\end{array}$ & Procedure & $\begin{array}{c}\text { Hospital } \\
\text { stay (d) }\end{array}$ & \\
\hline 1 & Male & 17 & Marfan & BAV & 30 & 14 & $\begin{array}{l}\text { Aortic } \\
\quad \text { regurgitation }\end{array}$ & 18 & Prolapse & $\begin{array}{l}\text { Mechanical } \\
\text { composite }\end{array}$ & 14 & 44 \\
\hline 2 & Male & 30 & AADA & TAV & 28 & 146 & $\begin{array}{l}\text { Aortic } \\
\quad \text { regurgitation }\end{array}$ & 32 & $\begin{array}{r}\text { Commissural } \\
\text { dehiscence }\end{array}$ & $\begin{array}{l}\text { Mechanical } \\
\text { aortic valve } \\
\text { replacement }\end{array}$ & 8 & 130 \\
\hline 3 & Female & 49 & Aneurysm & TAV & 26 & 45 & Endocarditis & 53 & Endocarditis & Stentless root & 48 & 102 \\
\hline 4 & Male & 38 & Aneurysm & TAV & 28 & 30 & $\begin{array}{l}\text { Aortic } \\
\quad \text { regurgitation }\end{array}$ & 40 & $\begin{array}{l}\text { Prolapse, } \\
\text { retraction, } \\
\text { perforation }\end{array}$ & Ross & 13 & 81 \\
\hline 5 & Male & 45 & Aneurysm & BAV & 30 & 19 & $\begin{array}{l}\text { Aortic } \\
\quad \text { regurgitation }\end{array}$ & 46 & Prolapse & Cusp plication & 10 & 69 \\
\hline 6 & Male & 18 & Marfan & TAV & 30 & 8 & $\begin{array}{l}\text { Aortic } \\
\quad \text { regurgitation }\end{array}$ & 19 & $\begin{array}{l}\text { Retraction, } \\
\text { inadequate } \\
\text { commissural } \\
\text { height }\end{array}$ & $\begin{array}{l}\text { Cusp } \\
\quad \text { augmentation }\end{array}$ & 9 & 50 \\
\hline 7 & Female & 48 & Marfan & TAV & 26 & 111 & $\begin{array}{l}\text { Aortic } \\
\quad \text { regurgitation }\end{array}$ & 58 & Retraction & $\begin{array}{l}\text { Biologic aortic } \\
\text { valve } \\
\text { replacement }\end{array}$ & 17 & 46 \\
\hline 8 & Male & 46 & AADA & BAV & 28 & 113 & Endocarditis & 56 & Endocarditis & $\begin{array}{l}\text { Biologic aortic } \\
\text { valve } \\
\text { replacement }\end{array}$ & 13 & 43 \\
\hline 9 & Male & 35 & Aneurysm & TAV & 28 & 5 & $\begin{array}{l}\text { Aortic } \\
\quad \text { regurgitation }\end{array}$ & 35 & $\begin{array}{l}\text { Prolapse, } \\
\text { perforation, } \\
\text { inadequate } \\
\text { commissural } \\
\text { height }\end{array}$ & $\begin{array}{l}\text { Cusp repair, } \\
\text { remodeling } \\
26 \mathrm{~mm}\end{array}$ & 9 & 20 \\
\hline 10 & Female & 45 & Aneurysm & BAV & 28 & 2 & $\begin{array}{l}\text { Aortic } \\
\quad \text { regurgitation }\end{array}$ & 45 & $\begin{array}{l}\text { Prolapse, } \\
\text { perforation, } \\
\text { inadequate } \\
\text { commissural } \\
\text { height }\end{array}$ & $\begin{array}{l}\text { Cusp repair, } \\
\text { remodeling } \\
24 \mathrm{~mm}\end{array}$ & 12 & 20 \\
\hline 11 & Male & 36 & Aneurysm & UAV & 30 & 6 & $\begin{array}{l}\text { Aortic } \\
\quad \text { regurgitation }\end{array}$ & 36 & $\begin{array}{l}\text { Inadequate } \\
\text { commissural } \\
\text { height, } \\
\text { inadequate } \\
\text { valve } \\
\text { configuration }\end{array}$ & $\begin{array}{l}\text { Bicuspidization, } \\
\text { remodeling } \\
26 \mathrm{~mm}\end{array}$ & 7 & 19 \\
\hline 12 & Male & 36 & AADA & TAV & 30 & 161 & $\begin{array}{l}\text { Aortic } \\
\quad \text { regurgitation }\end{array}$ & 50 & $\begin{array}{l}\text { Retraction, } \\
\text { commissural } \\
\text { dehiscence }\end{array}$ & $\begin{array}{l}\text { Mechanical } \\
\text { aortic valve } \\
\text { replacement }\end{array}$ & 7 & 11 \\
\hline 13 & Male & 35 & AADA & TAV & 28 & 3 & $\begin{array}{l}\text { Aortic } \\
\quad \text { regurgitation }\end{array}$ & 35 & $\begin{array}{l}\text { Prolapse, } \\
\text { perforation, } \\
\text { inadequate } \\
\text { commissural } \\
\text { height }\end{array}$ & $\begin{array}{l}\text { Cusp repair, } \\
\text { remodeling } \\
26 \mathrm{~mm}\end{array}$ & 16 & 3 \\
\hline
\end{tabular}

Pt. no., Patient number; $B A V$, bicuspid aortic valve; $A A D A$, acute aortic dissection type A; $T A V$, tricuspid aortic valve; $U A V$, unicuspid aortic valve.

2, 3, 7, 8, and 12; Table 1) of 29 reimplantation procedures during the study period. The primary operation had been performed at other institutions for the remaining 8 patients. During the same period, $32(5.2 \%)$ of 620 patients underwent aortic valve-related reoperation after root remodeling. These latter patients were not analyzed for the present study. All patients gave their consent for the present analysis, and the ethics committee approved the analysis and publication in anonymized fashion.
The age of the study patients at the initial procedure was 17 to 49 years. Of the 13 patients, 10 were men. The clinical characteristics of Marfan syndrome were present in 3 patients, and 4 underwent surgery for acute aortic dissection type A (Table 1). All had undergone the typical aortic valve reimplantation procedure. ${ }^{1}$ In 7 of the 8 operations performed at other institutions (patients 4, 5, 6, 9, 10, 11, and 13; Table 1) Teflon-pledgetted sutures (DuPont, Wilmington, Del) were used for the lower suture line. 


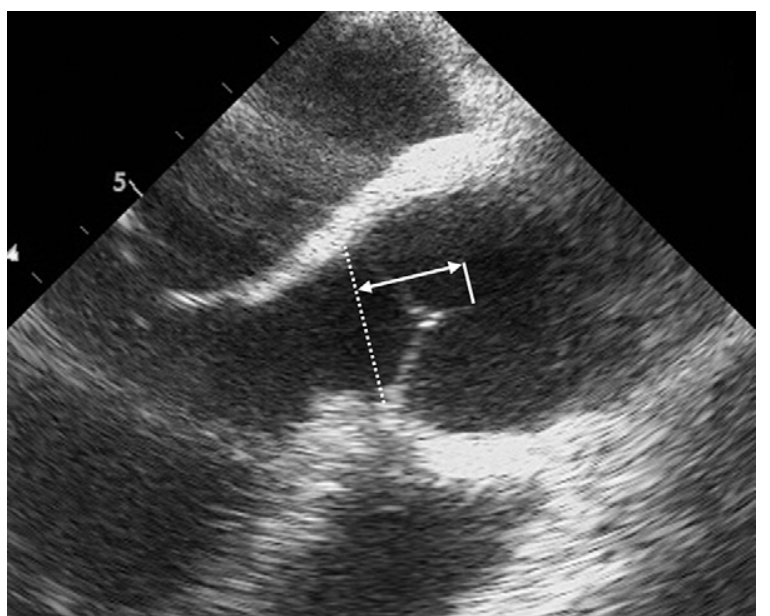

FIGURE 1. Intraoperative transesophageal echocardiogram after aortic root remodeling. Adequacy of cusp configuration determined by measurement of effective height. Dotted line indicates level of the basal ring or "annulus." The effective height is the distance between the central free cusp margins and the annular level orthogonal to the latter.

The interval between the initial procedure and reoperation was 6 weeks to 13 years. At reoperation, the age range was 18 to 58 years (mean, $40 \pm 13$ years). The indication for reoperation was severe aortic regurgitation in 11 and aortic valve endocarditis in 2 ; in 1 of these patients, extensive perivalvular abscess cavities were present.

In all patients, computed tomography or magnetic resonance imaging was performed to rule out the proximity of the ascending aorta to the sternum. The chest was reopened through a median sternotomy, and the patient connected to extracorporeal circulation through cannulation of the aortic arch and right atrium. In the patient with previous total arch replacement, the femoral artery was used for arterial inflow. The heart and ascending aorta were mobilized. The ascending aorta was clamped, preferably above the graft, the graft opened, and cardioplegia given directly into the coronary ostia $(\mathrm{n}=12)$ or the coronary sinus $(\mathrm{n}=1)$.

The graft was opened using a transverse incision approximately $1 \mathrm{~cm}$ above the level of the commissures. The aortic valve was carefully inspected. The commissural height was assessed by visual inspection, and a suboptimal height assumed to be present if the height difference between the nadir of the sinus and commissures was less than $2 \mathrm{~cm}$. Cusp retraction was ruled out or confirmed by measuring the maximum tissue height between the aortic insertion and central free margin. Cusp configuration was determined by measurement of the effective height (ie, the height difference between the basal ring or annular plane and the central free cusp margin). ${ }^{11}$ Intraoperatively, this was performed with a caliper. In addition, the effective height was determined using intraoperative transesophageal echocardiography (Figure 1). Cusp prolapse was assumed if the effective height was $8 \mathrm{~mm}$ or less ${ }^{11,12}$ in the presence of normal tissue height $(>17 \mathrm{~mm})$. The decision for valve replacement or repair was primarily determined by the presence or absence of cusp retraction and the presence of concomitant root pathology (ie, root abscess in the presence of endocarditis). The wishes of the carefully informed patient were also taken into consideration regarding the choice of the procedure.

\section{Intraoperative Findings}

Prolapse, defined by an abnormally low effective height in the presence of adequate tissue height, was found in 6 cases and occurred within the first 30 months postoperatively. Cusp retraction was observed in 4 cases 8 to 161 months after the initial procedure (Figure 2). Cusp perforations were seen in 6 patients. In 2 of these, the perforations were due to endocarditic cusp destruction 45 and 113 months postoperatively. In the remaining 4 patients, perforations were observed in close proximity to the nadir of the cusps and the Teflon pledgets (DuPont) used for the lower suture line 2 to 30 months after valve reimplantation. An inadequate commissural height was seen in 5 patients. It could be corrected by repeat root replacement with elevation of the commissures in 4 patients with otherwise preserved cusp tissue. Commissural dehiscence was observed in 2 patients. Both patients had

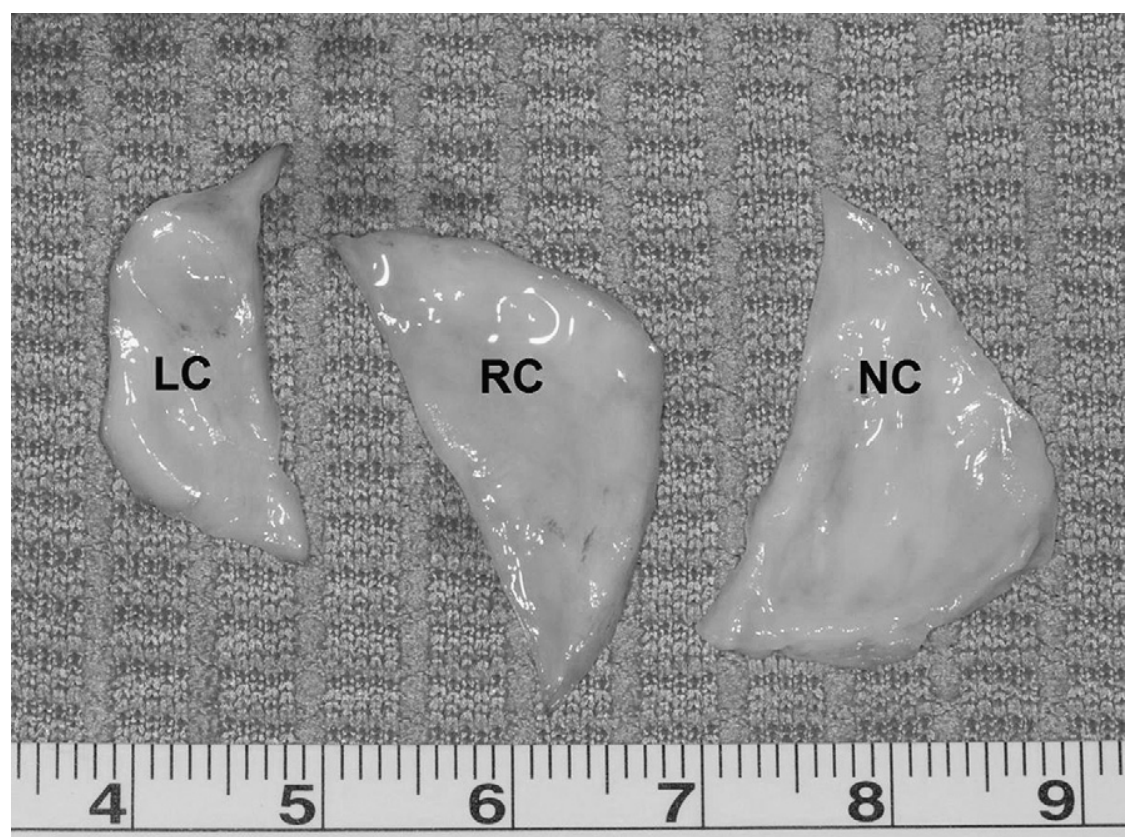

FIGURE 2. Intraoperative photograph of excised aortic cusps from patient with Marfan syndrome 10 years after valve reimplantation (patient 7). In particular, left and right coronary cusps are retracted. $L C$, Left coronary; $R C$, right coronary; $N C$, noncoronary. 
initially undergone surgery for acute type A dissection. An inadequate previous valve repair was found in 1 patient, in whom the original unicuspid morphology of the aortic valve had been treated by commissurotomy without correcting the concomitant commissural hypoplasia.

\section{Operative Management}

Valve replacement was performed in 4 patients in the presence of endocarditis $(\mathrm{n}=1)$, commissural detachment $(\mathrm{n}=2)$, or cusp retraction $(\mathrm{n}=1)$. The cusps were excised similar to primary aortic valve replacement. Teflon (DuPont) pledgetted inverting mattress sutures were placed, taking the annular tissue and proximal margin of the Dacron graft. A stented biologic $(n=2)$ or mechanical $(n=2)$ valve was implanted in a typical fashion. The Dacron graft was then closed by continuous suture, and the operation completed in standard fashion.

Cusp repair was performed in 2 patients (patients 5 and 6) in whom the cusp tissue appeared to be prolapsing (patient 5 ) or only mildly retracted (patient 6). In both, the wish of the patient was to avoid anticoagulation at all costs, and a pulmonary autograft was not an option because of patient age or the presence of Marfan syndrome. The operative details were similar to those for valve replacement. In the first patient, prolapse was corrected by plication of the free margin ${ }^{13,14}$; in the second, the cusps were augmented with pericardial patches.

A decision for repeat root replacement was made if the cusp tissue appeared preserved and nonretracted (geometric height, $>18 \mathrm{~mm}$ ) and the valve was distorted primarily through an inadequate commissural height in the previous root procedure $(n=4)$. Root replacement was also performed in the presence of endocarditis with root abscess (patient 3), and in the patient who requested a Ross operation as the replacement option (patient 4). In 1 patient, the graft had not completely eliminated the aneurysmatic root (patient 1) owing to ventricular myocardium in the right sinus; this patient underwent composite replacement.

In these instances, the ascending aortic graft was transsected completely to enhance exposure of the aortic valve and root. The old vascular graft was dissected and removed. If dissection proved difficult in the region of the coronary ostia, a limited remnant of Dacron was left on the ostium. The coronary arteries were mobilized conservatively to allow subsequent tension-free anastomosis to the new aortic graft. In the patients with residual aneurysmatic dilation (patient 1) or endocarditis and perivalvular abscesses (patient 3 ), the left ventricular outflow tract was sufficiently debrided, and a composite replacement of the valve and aorta was performed (Table 1).

For repeat valve preservation, care was taken to remove all prosthetic material potentially limiting commissural height and mobility. Only minimal remnants of the graft were left basally in 1 patient in whom this was thought not to interfere with subsequent valve repair. Stay sutures were then placed in the commissural tissue for optimal exposure, and the basal components of the commissures were mobilized, if this had been incomplete in the previous operation. The cusps were carefully inspected for structural integrity. Any perforations were closed by implantation of a pericardial patch into the defect using continuous polypropylene suture (Prolene 6-0; Ethicon, Hamburg, Germany). In all instances, a decision in favor of root remodeling as the reoperative procedure was made. A Dacron graft was chosen according to patient size (body surface area $<2 \mathrm{~m}^{2}$, 24-mm graft; for larger patients, a 26-mm graft was taken). It was trimmed to create 3 (in tricuspid morphology, $\mathrm{n}=2$ ) or 2 (in unicuspid or bicuspid morphology, $\mathrm{n}=2$ ) symmetric tongues. The graft was sutured into the aortic root with the suture following the cusp insertion lines. Care was taken to allow for excess graft length in the sinuses to avoid any commissural restriction through the prosthesis.

Cusp configuration was assessed by measuring the effective height. ${ }^{11}$ Any prolapse, defined as an effective height of less than $9 \mathrm{~mm}$, was corrected by central plication of the free cusp margin. ${ }^{13,14}$ In addition, an equal level of the free margins was ascertained visually. In the patient with previous tricuspidization of a unicuspid valve, the rudimentary right cusp was excised, and the valve was bicuspidized with 2 pericardial patches. ${ }^{15}$ Cusp perforations were closed by insertion of pericardial patches. In the presence of marked annular dilation $(>28 \mathrm{~mm})$, a polytetrafluoroethylene suture was placed on the outside at the level of the nadir of all sinuses. It was then tied around a 25-mm Hegar dilator.

The coronary ostia were implanted directly into the new graft. In only 1 patient was a short interposition graft (6-mm Dacron) believed necessary between the left ostium and the aortic graft because of the poor tissue quality of the ostium. The new aortic graft was then connected to the distal ascending aorta, the heart de-aired, and coronary circulation resumed. Intraoperative valve function was determined by transesophageal echocardiography (Vivid E9; General Electric, Fairfield, Conn; Sequoia; Siemens, Erlangen, Germany) using established criteria. ${ }^{16}$

All patients were followed up clinically and with transthoracic echocardiography.

For analysis, the mean \pm standard deviation was calculated. A KaplanMeier analysis was performed (SPSS, Chicago, Ill) to determine actuarial survival and freedom from valve-related complications \pm standard error.

\section{RESULTS}

The morphologic causes of regurgitation were cusp prolapse in 6 , cusp retraction in 4 , cusp perforation in 6 , inadequate commissural height in 5 , commissural dehiscence in 2 , and inadequate valve configuration in 1 , alone or combined.

The myocardial ischemic times of the reoperations ranged from 35 to 125 minutes (mean, 80 minutes). For repeat valve-preserving root replacement, myocardial ischemia ranged from 87 to 125 minutes (mean, 109 minutes). The length of hospital stay was influenced by the underlying diagnosis. For elective reoperations, the mean intensive care stay was 1 day, and the hospital stay ranged from 7 to 17 days. In the 2 patients with active endocarditis, a prolonged hospital stay was necessary. The duration of follow-up at ranged from 3 to 130 months.

One patient (patient 1) died 4 years after reoperation of sudden cardiac death; an autopsy was not performed. All other patients were alive and well at the last follow-up visit. The 5-year survival rate was thus $86 \% \pm 13 \%$.

Failure of the repeat operation with the need for additional surgery on the aortic valve occurred in 1 patient (patient 5). He developed endocarditis of the repaired aortic valve with consecutive regurgitation that required tertiary replacement 2 years after the initial redo operation. Two operations were unrelated to the aortic valve. One patient required mitral valve repair 4 months after the index operation; another underwent thoracoabdominal aortic replacement after 2 months. The 5-year rate of freedom from valve-related complications was $78 \% \pm 14 \%$. Valve failure could not be excluded in the patient who died of sudden death, and the patient was considered to have had possible valve thrombosis.

\section{DISCUSSION}

Aortic valve reimplantation has evolved into an accepted form of valve-preserving aortic replacement for aortic 
aneurysm or dissection. Anticoagulation can be avoided, and the incidence of thromboembolic complications has been low. Secondary failure of the aortic valve with early or late development of relevant aortic regurgitation has been the most important valve-related complication observed by us and others. ${ }^{3,6-9,17}$

At this time, limited information is known on the predictors of postoperative progressive aortic regurgitation, the most common reason for reoperation. Pethig and colleagues ${ }^{10}$ described different configurations of the aortic valve that predisposed to a greater risk of reoperation for valve failure. The investigators did not, however, determine the exact anatomic correlates and speculated that only the level of reimplantation within the graft explained normal or abnormal postoperative configuration. It is difficult to change the operative strategy of reimplantation using this information (ie, whether the lower or upper suture line should be modified). Other reports have simply stated that reoperations were performed, without giving details. Thus, the present study is, to our knowledge, the first report on the anatomic findings at reoperation after aortic valve reimplantation and their management.

We have previously found that a reduction of sinus dimensions, in particular at the sinotubular level, can induce cusp prolapse as a simple geometric consequence. ${ }^{18}$ This observation led to the development of the effective height concept $^{11}$ (ie, measuring the height difference between the basal ring and free margins in a closed (diastolic) position. In retrospect, some of the observations of Pethig and colleagues ${ }^{10}$ could also be classified as generalized prolapse at reoperation, which was performed by 1 of us (H.J.S.) in the present study in 2 patients. We recently analyzed the predictors of aortic valve failure in a larger series and found the reduction of very large roots to be a risk factor, most likely because of unrecognized prolapse left at valvepreserving surgery. ${ }^{19}$

Our current findings have revealed the different mechanisms of aortic regurgitation, some of which might be related to the technical realization of the initial procedure. In the patients who presented with early failure (within the first year postoperatively), cusp prolapse with tissue redundancy was the predominant pathologic finding (Figure 3,A). Initially we thought this was only due to the reduction of the intercommissural distance, which we have found to cause cusp prolapse. ${ }^{18}$ In the more recent reoperations, we also observed an inadequately low commissural height, which might have had an additive effect on the generation of prolapse. The importance of the commissural height was supported by the finding that after repeat valvepreserving root replacement, most of the prolapse was eliminated, and only limited additional cusp plication led to normal valve form and function (Figure 3, B). This is an important finding and has reinforced our attempts to achieve maximum commissural height in every primary procedure,
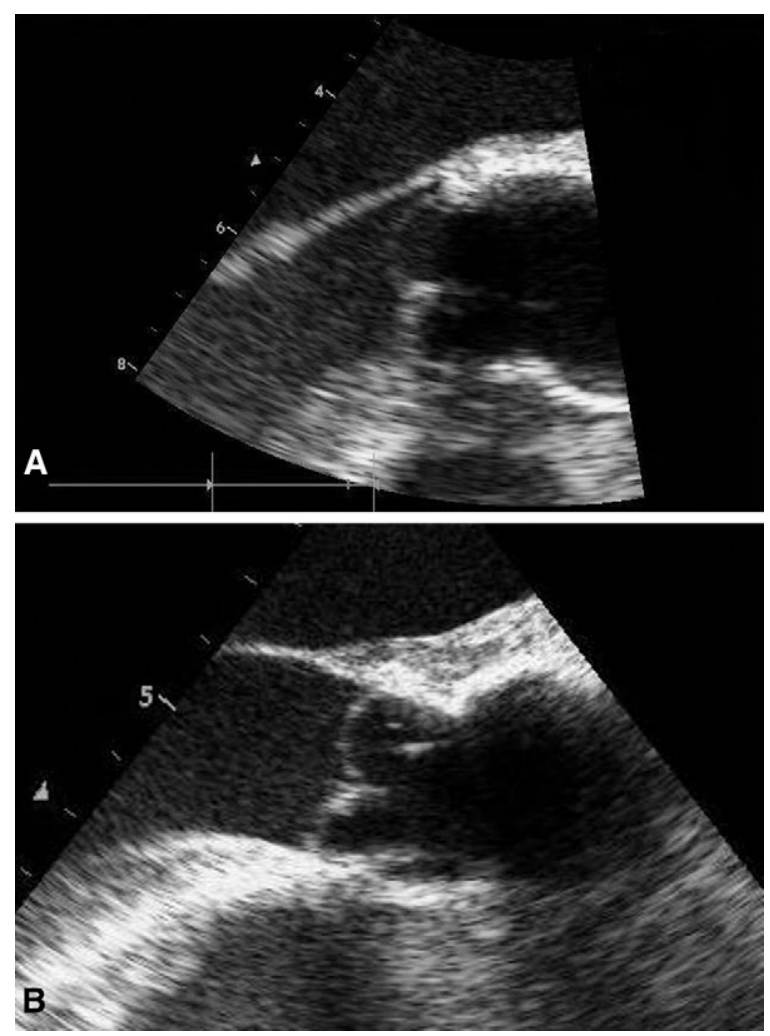

FIGURE 3. A, Preoperative transesophageal echocardiogram of 35-yearold patient 3 months after valve reimplantation (patient 13). The cusps, including the coaptation line, are below the level of the vascular graft, indicating extensive prolapse. B, Postoperative transesophageal echocardiogram of patient 13 after reoperative root remodeling. The configuration of the valve is normalized, although additional cusp plication was performed only on the left coronary cusp.

in addition to aiming for an adequate effective height. ${ }^{11} \mathrm{At}$ present, no clinical data are available on the normal height of the commissures, and predicted values would be important to ensure the reproducibility of the procedure with good results. Future systematic studies are needed to address this aspect. An unexpected finding was the observation of cusp erosions in the proximity of Teflon pledgets (DuPont), when these had been used for the lower suture line in the primary procedure. It appears conceivable that the combination of cusp prolapse and Teflon (DuPont) leads to direct contact between basal cusp and the Teflon (DuPont). This might then lead to early erosion or to accelerated development of retraction (patient 4). Although it is difficult to generalize from the details of so few patients, it is our impression that the use of Teflon pledgets (DuPont) should be reconsidered. We have not found them necessary for aortic valve reimplantation.

The predominant lesions in the patients with late failure ( $>1$ year) who had undergone their primary surgery at our institution were cusp retraction and endocarditic destruction. In addition, 2 instances of commissural detachment 
occurred in patients with dissection of that commissure as a part of the acute aortic dissection. All 3 causes occurred late after surgery and did not seem to be related to the performance of the initial procedure. It might be argued that the root with the dissected commissures should not have been preserved. However, we have used valve-preserving surgery in more than 60 instances of acute dissection, and this complication has occurred only twice. A different mechanism was present in the patient in whom a unicuspid aortic valve had not been recognized and the resulting valve repair had resulted in inadequate commissural and cusp configuration.

The management at reoperation consisted of valve replacement in most patients with aortic valve failure occurring after the first 6 months and caused by cusp retraction or endocarditic destruction. Isolated repair of cusp prolapse was performed only once and resulted in normalization of valve function. The need for secondary replacement in that patient resulted from destructive changes after healed endocarditis. Another exception was the 19-year-old patient with Marfan syndrome (patient 6), who did not want a mechanical valve, and in whom we created a bicuspid valve within the vascular graft. This resulted in adequate valve function for the past 4 years. All operations limited to the aortic valve proved to be surgically straightforward, in that the old graft was simply opened and a procedure similar to a primary valve operation performed.

Composite replacement seemed necessary in 3 patients. In patient 1 , placement of the lower suture line and graft had been difficult because the aortoventricular junction was much higher than the basal ring. In the other 2 patients, the choice of an autograft or the existence of extensive perivalvular abscess made this approach mandatory. Also, the technical complexity was limited in these patients, and only a limited myocardial ischemic time was required.

Reoperation as repeat valve-preserving root replacement was performed in those with early failure only (ie, within the first 6 months). This to us initially appeared as a potentially challenging and unpredictable operation. However, we believed the avoidance of prosthesis-related complications through preservation of the native aortic valve would be an interesting option. We were impressed that in these reoperations the low commissural height could be corrected by taking down the previous surgery and performing a new primary procedure. Intuitively, we decided in favor of root remodeling as the reoperation to minimize the dissection in the stiff and edematous area close to the aortoventricular junction. In addition, our experience has been mostly based on root remodeling. ${ }^{19}$ This does not imply that the same results cannot be obtained by repeat reimplantation. Despite choosing a smaller graft than that of the primary procedure, this partially resolved most of the pre-existent prolapse seen in patients 9, 10, and 13 (Figure 3, $A$ and $B$ ). Residual prolapse could be easily corrected by standard cusp plication. ${ }^{13,14}$ This approach was easiest in the first 3 months. In the patient with unrecognized unicuspid morphology, a bicuspidizing repair ${ }^{15}$ was added. At last follow-up, no recurrence has been observed in these patients, making redo valve preservation an interesting option for early valve failure in experienced hands. In retrospect, valve preservation might also have been an option in the first patient of this reoperative series. However, at that time, the characteristics and mechanism of cusp prolapse and the possibilities of correcting it had not been established.

This is, to our knowledge, a first systematic report on the management of valve failure after aortic valve reimplantation. The number of patients was limited, and conclusions from our analysis must be drawn cautiously. At present, the results of valve repeat reconstruction are relatively short term, and longer follow-up is needed. The data did not allow analysis of the clinical results of valve reimplantation in general and was not the purpose of the present report. Certain aspects of valve configuration (eg, commissural height) are still determined by visual assessment. In the absence of published normal data, this is the best that can be done. Additional research is necessary to define the ideal dimensions in aortic valve reimplantation. Ideally, the surgeon should have normal or predicted data, not only for the effective height, but also for the commissural height and size of the aortoventricular junction. These "normal" values should not only allow better definition of the reasons for valve failure, but also further improve the results of valve reimplantation as a primary operation.

\section{CONCLUSIONS}

Cusp prolapse is an important early failure mode of the reimplantation procedure. Prolapse can be induced by reduction of the intercommissural distance and can also be the consequence of an inadequate commissural height. Valve preservation at reoperation is an option and should also include restoration of the normal commissural height. Late failures will involve cusp retraction in a relevant proportion of instances and are probably best treated by aortic valve replacement.

\section{References}

1. David TE, Feindel CM. An aortic valve-sparing operation for patients with aortic incompetence and aneurysm of the ascending aorta. J Thorac Cardiovasc Surg. 1992; 103:617-21.

2. Sarsam MA, Yacoub M. Remodeling of the aortic valve annulus. J Thorac Cardiovasc Surg. 1993;105:435-8.

3. David TE, Maganti M, Armstrong S. Aortic root aneurysm: principles of repair and long-term follow-up. J Thorac Cardiovasc Surg. 2010;140:S14-9.

4. Yacoub MH, Gehle P, Chandrasekaran V, Birks EJ, Child A, Radley-Smith R. Late results of a valve-preserving operation in patients with aneurysms of the ascending aorta and root. J Thorac Cardiovasc Surg. 1998;115:1080-90.

5. Aicher D, Langer F, Lausberg H, Bierbach B, Schäfers HJ. Aortic root remodeling: ten-year experience with 274 patients. J Thorac Cardiovasc Surg. 2007; 134:909-15.

6. Kallenbach K, Hagl C, Walles T, Leyh RG, Pethig K, Haverich A, Harringer W. Results of valve-sparing aortic root reconstruction in 158 consecutive patients. Ann Thorac Surg. 2002;74:2026-32. 
7. Shrestha M, Baraki H, Maeding I, Fitzner S, Sarikouch S, Khaladj N, et al. Longterm results after aortic valve-sparing operation (David I). Eur J Cardiothorac Surg. 2012;41:56-61.

8. Zehr KJ, Orszulak TA, Mullany CJ, Matloobi A, Daly RC, Dearani JA, et al. Surgery for aneurysms of the aortic root: a 30-year experience. Circulation. 2004; 110:1364-71.

9. Burkhart HM, Zehr KJ, Schaff HV, Daly RC, Dearani JA, Orszulak TA. Valvepreserving aortic root reconstruction: a comparison of techniques. J Heart Valve Dis. 2003;12:62-7.

10. Pethig K, Milz A, Hagl C, Harringer W, Haverich A. Aortic valve reimplantation in ascending aortic aneurysm: risk factors for early valve failure. Ann Thorac Surg. 2002;73:29-33.

11. Schäfers HJ, Bierbach B, Aicher D. A new approach to the assessment of aortic cusp geometry. J Thorac Cardiovasc Surg. 2006;132:436-8.

12. Bierbach BO, Aicher D, Issa OA, Bomberg H, Gräber S, Glombitza P, et al. Aortic root and cusp configuration determine aortic valve function. Eur J Cardiothorac Surg. 2010;38:400-6.

13. Langer F, Aicher D, Kissinger A, Wendler O, Lausberg H, Fries R, et al. Aortic valve repair using a differentiated surgical strategy. Circulation. 2004;110: II67-I173.
14. Aicher D, Langer F, Adam O, Tscholl D, Lausberg H, Schäfers HJ. Cusp repair in aortic valve reconstruction: does the technique affect stability? J Thorac Cardiovasc Surg. 2007;134:1533-8.

15. Schäfers HJ, Aicher D, Rodionycheva S, Lindinger A, Rädle-Hurst T, Langer F, et al. Bicuspidization of the unicuspid aortic valve: a new reconstructive approach. Ann Thorac Surg. 2008;85:2012-8.

16. Zoghbi WA, Enriquez-Sarano M, Foster E, Grayburn PA, Kraft CD, Levine RA, et al. American Society of Echocardiography. Recommendations for evaluation of the severity of native valvular regurgitation with twodimensional and Doppler echocardiography. J Am Soc Echocardiogr. 2003; 16:777-802.

17. Cameron DE, Alejo DE, Patel ND, Nwakanma LU, Weiss ES, Vricella LA, et al. Aortic root replacement in 372 Marfan patients: evolution of operative repair over 30 years. Ann Thorac Surg. 2009;87:1344-9.

18. Schäfers HJ, Aicher D, Langer F, Lausberg HF. Preservation of the bicuspid aortic valve. Ann Thorac Surg. 2007;83:S740-5.

19. Kunihara T, Aicher D, Rodionycheva S, Groesdonk HV, Langer F, Sata F, et al. Preoperative aortic root geometry and postoperative cusp configuration primarily determine long-term outcome after valve-preserving aortic root repair. J Thorac Cardiovasc Surg. August 19, 2011 [Epub ahead of print]. 